\title{
THE SPACES OF MEMORY AND THEIR TRANSMEDIATIONS. ON THE LIVES OF EXOTIC IMAGES AND THEIR MATERIAL EVOCATIONS
}

\author{
Benjamin Schmidt
}

\section{Introduction. The Spaces of Memories}

In Greek mythology, the Titaness Mnemosyne-who personified memory and bequeathed to us the word mnemonic - is associated mostly with language and words and with the muses, including history (Clio) and poetry (Calliope). She is also a goddess of time, which reflects an association of memory and temporality. Yet the ars memoriae (art of memory) of the Ancients, inherited with great enthusiasm by Renaissance practitioners, links memory to the additional qualities of space and visuality: memory could also be pictorial and topographic (as well as textual). The Jesuit missionary Matteo Ricci famously invoked a sense of space and of the visual to convey and solidify his memory of European and Christian learning, which he carried with him to the East in the late sixteenth century (as a 'memory palace'). Ricci's mode of memory was distinctly and vividly graphic and-by dint of his exotic travels-even geographic. ${ }^{1}$

In contemplating the qualities of early modern memory, it is helpful to recall the importance of space as well as time-the 'landscape' of memory, as it has been characterised in other contexts ${ }^{2}$ - and how a sense of where we are (or have been) can shape processes of recollection and memorialisation. For if memory tends to be affiliated instinctively with time- history and our sense of the past - it plays an important role, too, in the perception of space-geography and our sense of place. The first category - time - resonates in all manner of personal, historical, and political registers, of course. Meanwhile, the second-space-allows us

\footnotetext{
${ }^{1}$ Jonathan D. Spence, The memory palace of Matteo Ricci (New York: Penguin Books, 1985).

2 Simon Schama, Landscape and memory (New York: Vintage Books, 1996); Sabine Marschall, Landscape of memory. Commemorative monuments, memorials and public statuary in post-apartheid South Africa (Leiden: Brill, 2009).
} 
not only to situate our memories (as Ricci did) in concrete spaces; but also to project onto spaces and landscapes memories that likewise incorporate personal, political, and social identities, not to mention national and imperial sensibilities. The significance of space to the project of remembering is justly underscored by Benedict Anderson in his history of collective identity and national memory, Imagined Communities. In the revised edition of that canonical book, Anderson includes a chapter on maps and geography to make the basic point that the memorialisation and articulation of space plays a vital role in the construction of 'imagined communities'. Memory expresses itself, Anderson properly points out, in geography no less than history. Mnemosyne's nine muses, that is to say, might have been augmented. ${ }^{3}$

Space is critical to an understanding of early modern memory in more ways than one. There were, to be sure, many landscapes of memory and many means of memorialising through space-in early modern Europe no less than in other moments and places in history. But early modern Europe also witnessed the dramatic augmentation of its spaces by dint of its global expansions and its flourishing interest in overseas worlds. Ricci was but one of many who described and memorialised his experiences abroad, and the field of geography thrived in these years. More generally, not only did the field of geography prosper, but so did the spaces and forms used to convey geography: the sites and sources, the methods and media, enlisted to transmit images and memories of the world. Early modern Europe was positively awash in geography; geo-memories (to coin a term) circulated in a dizzying variety of forms, recording Europe's sense of space and place in an expanding world. These sources included the putatively personal form of travel accounts as well as the less personal yet phenomenally popular genre of 'descriptions' of foreign lands; printed maps both terrestrial and maritime, along with cityscapes and numerous other manner of vedute; paintings of foreign landscapes and ethnographic subjects; exotic natural specimens and the myriad other objects collected for early modern cabinets of curiosities; and a wide range of material (socalled decorative) arts, which were embellished with exotic motifs and implicitly designed to covey to early modern consumers a sense of the world. Or better, senses of the world, since early modern geography served

3 Benedict Anderson, Imagined communities. Reflections on the origin and spread of nationalism (2nd ed., London: Verso, 1991). The key chapter, added by Anderson to his revised edition, is titled 'Census, Map, Museum', with the cartographic element especially pointing toward the visual. 
not only to introduce European audiences to the world, yet also to shape the several meanings of their world. In its many forms, geography served as an important conduit of global meaning and global memories. Images of the world and conceptions of the world passed through myriad sources and media, thereby furnishing a much valued - if also much handledform of memory. Geography, not unlike its global informants, travelled vigorously.

Early modern geography in this way imparted instructive forms of meaning and 'memory'. Sources of geography might document the personal experience of this or that traveller or artist, merchant or colonial agent overseas. Yet they do this more often than not in ways that move beyond an individual source and-in their wider iterations and circulations - in ways that register larger political and religious engagement with the world. Early modern geography, furthermore, expressly memorialised overseas sites and events - this applies for variants of modern and medieval geography, too, of course-and this memory function can be a central aspect of these sources. Richard Hakluyt offered his Principal navigations, voyages, traffiques and discoveries of the English nation (as his celebrated collection of geography narratives was titled) 'to preserve certaine memorable exploits of late yeeres by our English nation achieved.'; and this assemblage of memories came to be known as 'the Prose Epic of the modern English nation', the very foundation of imperial Britannia. ${ }^{4}$ The conceit of overseas exploits as 'memorable' - the memorialisation of exotic geography-becomes a veritable commonplace in the growing body of materials produced over the seventeenth century, especially in the most intense moment of manufacture in the century's final decades. ${ }^{5}$ Johan Nieuhof (or more likely his publisher, Jacob van Meurs) presented his readers with a 'memorable sea and land journey' (gedenkwaerdige zee en lantreize), which would go on to become one of the most popular works of geography from this period (in this case, on China). And the prolific, stay-at-home geographer Olfert Dapper typically invoked the 'memorable' accounts he described in his numerous printed geographies of the world: the 'memorable occurrences' (gedenkwaerdige geschiedenissen) of

4 Richard Hakluyt, The principal navigations, voiages, traffiques and discoueries of the English Nation (London: Christopher Barker, 1589-160o). See also Anthony Froude, 'England's forgotten worthies', in Short studies on great subjects, 4 vols. (new ed., London: Longmans, Green, 1886-88), vol. 1, 446-447.

5 This moment of geography is explored in greater detail in Benjamin Schmidt, Inventing exoticism. Geography, globalism, and Europe's early modern world (Philadelphia: University of Pennsylvania Press, forthcoming 2014). 
the Ottoman empire; the 'memorable affairs' (gedenckwaerdig bedryf) of Qing China, and so on. ${ }^{6}$

There are two things to emphasise about these self-advertised memories. First, they are not bona fide memories in the simple sense that printed volumes by the likes of Dapper-a veelschrijver, or hack writer, who churned out a steady flow of books for his profit-minded publisherdid not offer a personal memory so much as the semblance of a memory, descriptions whose origins rested in actual fact with other travellers whose manuscripts had fallen into the hands of the publisher. These were, in short, manufactured memories. Second, memories in volumes of geography were delivered not simply as narrative recollections, but also-and also more prominently - as pictorial representations. For these textual allusions to processes of memorialisation belie the basic fact that geography in this period, especially in the form produced so richly and abundantly in the hub of geography that was the Netherlands, was a pronouncedly visual medium. In the second half of the seventeenth century, Dutch ateliers specialised in a brand of large, lavishly illustrated, emphatically graphic books, which were ambitiously translated and exported to the rest of Europe. ${ }^{7}$ Nieuhof and Dapper's volumes, like so many others that streamed out of the industrious workshops of Holland, were saturated with pictures; and these readily replicable iconographic forms lent themselves, easily and naturally, to the production and reproduction of memory. Pictures preserved memories-or at least, various forms of memories.

This essay examines these pictorial forms of global memory-icons, as it were, of the early modern exotic world; pictures worth (as it turns out) well more than a thousand words. It considers how they obtained and dispersed meaning in their many iterations, and it reflects on how sources of geography functioned to shift and shape new meanings as they moved

6 Johan Nieuhof, Gedenkwaerdige zee en lantreize door de voornaemste landschappen van West en Oostindien (Amsterdam, 1682). This book also incorporated materials from the China volume, Het gezantschap der Neerlandtsche Ost-Indische Compagnie, aan den grooten Tartarischen Cham, den tegenwoordigen keizer van China (Amsterdam, 1665), which advertised (in its full title) its own 'gedenkwaerdighste geschiedenissen'. See further Olfert Dapper, Gedenckwaerdig bedryf der Nederlansche Oost-Indische Maetschappye, op de kuste en in het keizerrijk van Taising of Sina (Amsterdam, 1670); Dapper, Naukeurige beschryving der eilanden, in de archipel der Middelantsche zee, en ontrent dezelve, gelegen (Amsterdam, 1688) and Naukeurige beschryving van gantsch Syrie, en Palestyn of Heilige Lant (Amsterdam, 1677), the full titles of which also invoke the 'memorable' qualities of geography.

7 V.D. Roeper and G.J.D. Wildeman, Reizen op papier. Journalen en reisverslagen van Nederlandse ontdekkingsreizigers, kooplieden en avonturiers, Jaarboek van het Nederlands Scheepvaart Museum Amsterdam (Zutphen: Walburg Pers, 1996). 
from source to source and from medium to medium. It looks, that is, at processes of transmediation: how sources (in this case, images extracted from geography) change in meaning when they transfer to different media, or how the medium, to invoke the famous dictum of Marshall McLuhan, could often be the message. ${ }^{8}$ Finally, it explores how shifts in meaning, or transmediations, might have influenced early modern Europe's 'memory' of the world it was coming to know in this critical age of exploration and empire.

\section{Memorable Khans and Mediated Despotism}

Pictures and prints pertaining to the non-European world, made in the decades surrounding 1700 - from the 1660 more or less through the 1730 - would have a profound influence over Europe's 'memory' of exotic space. There was a profusion of images produced in all manner of geography - much, if not most, emanating from workshops of the Netherlandsand these representations also circulated broadly across several media. ${ }^{9}$ The very range of these images - in terms of their subject matter, their market range, and the extent of their impact-is highly impressive. The conception of Chinese imperial power, for example, which would later come to define so-called Oriental despotism, derived to a striking degree from the engraved scene of the Qing emperor that opens Johan Nieuhof's 'most memorable' voyage to China, as the title page calls it (figure 12). ${ }^{10}$ First published by Jacob van Meurs in 1665, Nieuhof's account would turn out to be among the most popular works of geography produced in the early modern period. It appeared in something approaching a dozen separate editions - this does not include the numerous pirated and plagiarised versions - and these spanned the major languages of Europe. ${ }^{11}$ Its images, moreover, circulated even more broadly in other publications, other

8 Marshall McLuhan, Understanding media. The extensions of man (New York: McGrawHill, 1964).

9 Benjamin Schmidt, 'Mapping an exotic world. The global project of Dutch geography, circa 1700', in Felicity Nussbaum (ed.), The global eighteenth century (Baltimore and London: Johns Hopkins University Press, 2003), 19-37.

10 Johan Nieuhof, Het gezantschap der Neerlandtsche Ost-Indische Compagnie, aan den grooten Tartarischen Cham, den tegenwoordigen keizer van China. Waar in de gedenkwaerdighste geschiedenissen, die onder het reizen door de Sineesche landtschappen, Quantung, Kiangsi, Nanking, Xantung en Peking, en aan het keizerlijke hof te Peking, sedert den jare 1655 tot 1657 zijn voorgevallen (Amsterdam, 1665).

11 See John Landwehr, VOC. A bibliography of publications relating to the Dutch East India Company, 1602-180o (Utrecht: Hes \& De Graff, 1991). 


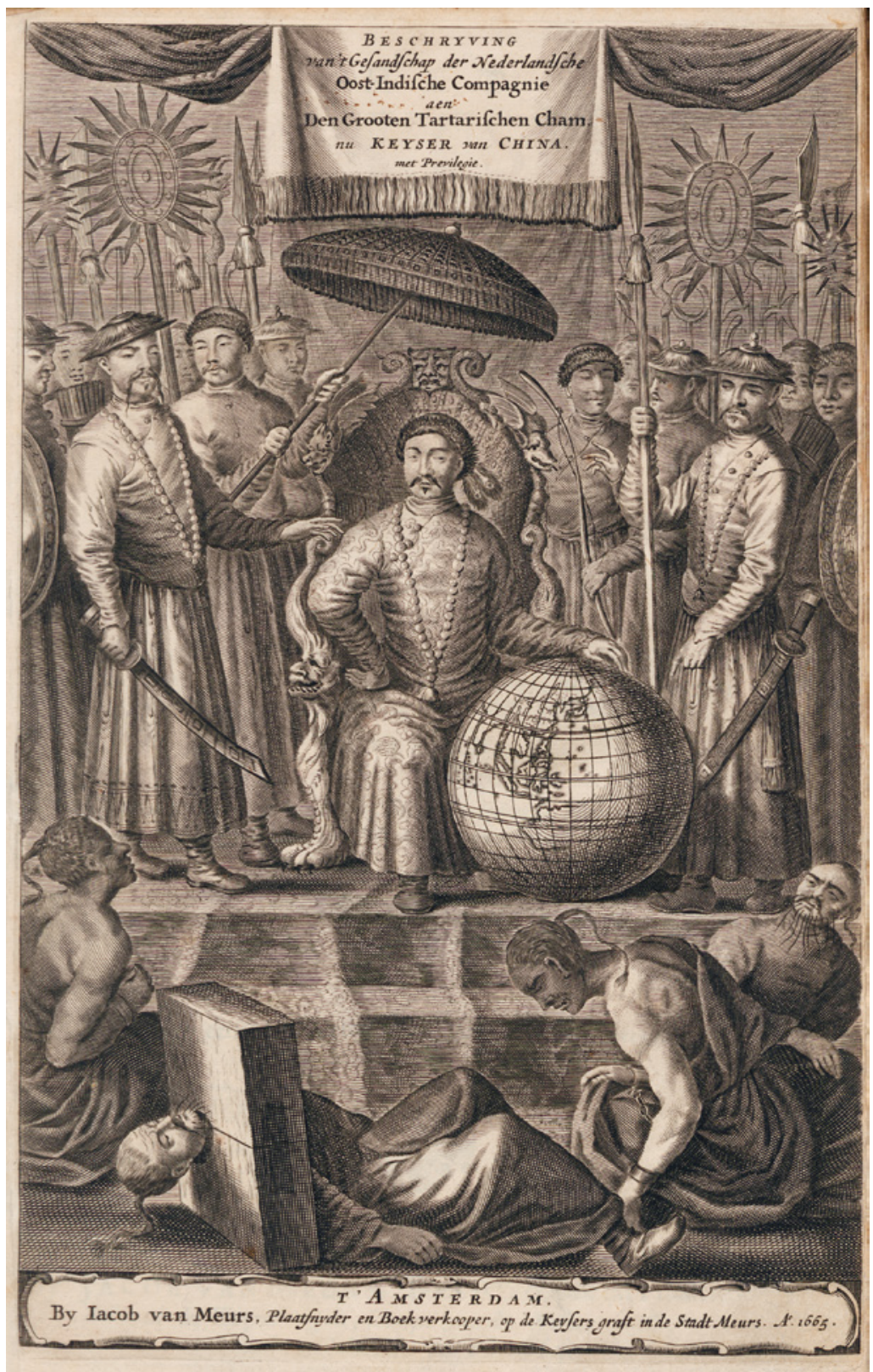

Fig. 12. Jacob van Meurs (workshop), frontispiece of Johan Nieuhof, Het gezantschap der Neerlandtsche Ost-Indische Compagnie, aan den grooten Tartarischen Cham, den tegenwoordigen keizer van China (Amsterdam: Jacob van Meurs, 1665), Universiteitsbibliotheek Leiden, Collectie N.H.K. 345. 
genres, and other media. To the European consumer of the later seventeenth and eighteenth centuries, they became icons of the Orient.

Nieuhof's enormously influential frontispiece was exemplary in this regard. An engraved, full-plate folio that serves as the opening illustration of the volume, the frontispiece centres on a regally dressed figure who sits, one arm akimbo, on a baroquely carved throne. The figure's second arm rests on a bulky globe, which displays the just-discernible outlines of China and its domains; the globe's round form mirrors that of a tilted parasol, which is held aloft by a lackey and crowns both the sitter and his throne. The engraving's protagonist-identified by the title as the Grand Tartar Cham, namely the Great Khan — positively radiates imperial hegemony. Surrounding the mighty, newly instated Qing emperor stands a fierce cadre of men bearing arms and banners, while at his feet a cluster of supplicants writhe in various forms of restraint: chains, manacles, and the cangue. These obsequious prisoners sprawled at the base of the engraving (just above the printer's cartouche) allude to the Khan's total control over his subjects' bodies, and the frontispiece image broadcasts, more generally, a message (also echoed in the text) of Chinese imperial puissance. It speaks, more globally, to contemporary European awe of the Khan's majesty and to the admiration-especially among certain elite European observers - of his absolute political and juridical control.

The image is presented ostensibly as a memory. It is meant to offer a snapshot, as it were, of a moment in Nieuhof's Chinese adventure and a record of a Dutch embassy to the imperial city. Yet a brief glance backward and forward show just how convoluted this memory could be, both in terms of the image's production and its afterlife. First, backward: Although attributed to the volume's putative author, there exists no original draft by Johan Nieuhof for this imaginative imperial passage, as, indeed, there could not be, since the scene did not take place-Nieuhof and his colleagues never actually obtained an audience with the emperor. And while the manuscript from Nieuhof's China voyage does contain an illustrated title page, this image bears no resemblance to the engraved frontispiece of the printed book. ${ }^{12}$ The latter derives, rather, from Van Meurs' workshop and not unlikely from the drafting table of the printer himself, who trained as an engraver. Yet the image does evoke a patina of memory. It extracts the figure for the Great Khan from an on-site drawing made by Nieuhof of

12 For the manuscript, see Leonard Blussé and R. Falkenburg (eds.), Johan Nieuhofs Beelden van een Chinareis, 1655-1657 (Middelburg: Stichting VOC, 1987). 
'an old [provincial] viceroy' whom the author met in his travels (figure 13). This sketched figure wears the same brocaded gown, beaded chain, furlined hat, and jaunty feathers as the engraved emperor. ${ }^{13}$ The printer, in other words, has gussied up this relatively austere, stand-alone sketch with layers of regal extravagance: the armed guards, humbled prisoners, and stately trappings of power. The combination of pomp and power, in all events, proved compelling. For while subsequent portraits of the Great Khan on his own are relatively rare, the imperial entourage appears as such across myriad prints and decorative arts. It served, unrevised, as the frontispiece to the French (1665), German (1666), and Latin (1668) editions of Nieuhof's book, while a copy of the design, mildly modified by the

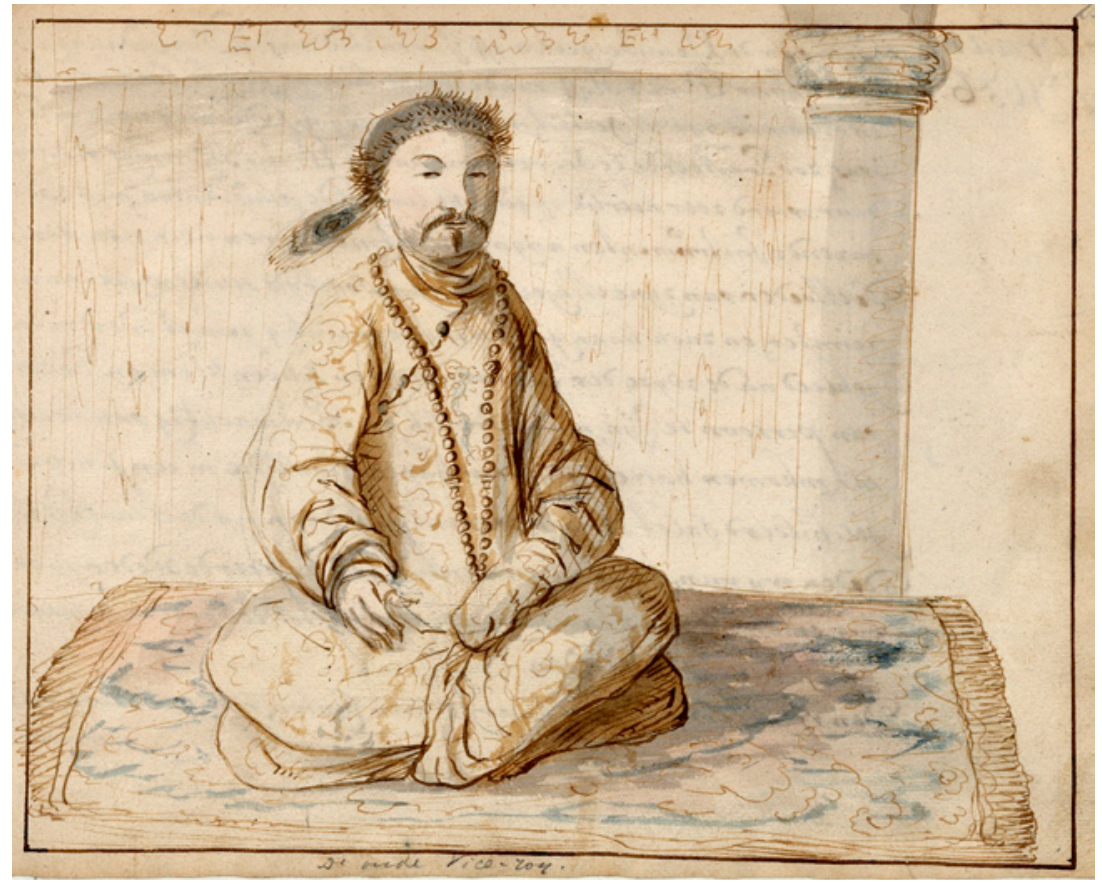

Fig. 13. Johan Nieuhof [?], drawing of a viceroy in 'Journaal van zommige voorvallen, inde voyagie vande E. Heeren Pieter de Goyer en Jacob Keyser, ambassadeurs, aande grootmachtige keizer van Chyna en Tartaryen, inde jaaren 1655, 56 \& 1657' (1659), folio 23; manuscript in the collection of the Société de Géographie, Bibliothèque Nationale, Paris.

13 Blussé and Falkenburg, Beelden van een Chinareis, between pp. 32 and 33. 
Bohemian etcher Wenceslaus Hollar, fronted the English edition of John Ogilby's Atlas Chinensis. ${ }^{14}$ Other, unrelated geographies of China adopted the basic layout of the image: enthroned emperor, flanking attendants, wretched supplicants. And it is highly ironic that the German publisher of Jean-Baptiste Du Halde's well-received Description geographique ... de L'empire de la Chine, a volume that purports to assemble Jesuit experiences in China-and a volume that, inter alia, was highly critical of those 'decorative' Dutch publications-lifted Van Meurs' design largely unchanged. This Du Halde edition appeared in the mid-eighteenth century and thereby indicates just how fixed this picture had become among Enlightened Europeans as an enduring image of imperial China. ${ }^{15}$

Yet, this image was not at all fixed. The memory of 'Nieuhof', massaged from the start, proved to be a thoroughly plastic specimen of memory, which could be further massaged and reconstituted as need be. And just as it would be a mistake to privilege the earlier forms as somehow more correct-Van Meurs' engraved adaptation of Nieuhof's sketched recollection of a vaguely allied figure who came to stand for the Grand Khan - it would also be wrong to fix on the printed figure or on any other single semiotics of the ensemble, or to discount any of the wider-ranging, later iterations of the Emperor of China (as the motif came to be called). For the image of the Khan certainly got around, and it soon moved on to other media, including the material arts, where it 'decorated' a range of goods: ceramics, silver, furniture, tapestry, and so on. And these other forms, needless to say, produced other meanings. Memories of place, that is to suggest, shifted not only with time but also with form; varying materials instigated varying messages. The astonishingly inventive 'Grieksche A Factory' of Delft, the leading European producers of tin-glazed earthenware in the second half of the seventeenth century, manufactured a vase with cover (ca. ${ }_{1675}-80$ ) that featured the emperor and his entourage, transposed virtually unchanged from Van Meurs' print (figure 14). The disciplined Chinese subjects in this arrangement are painted slightly off to the side of the imperial assembly, where a royal servant attends to their punishment. Yet rather than weakening the message of the Khan's omnipotent power, this

14 John Ogilby, An Embassy from the East-India Company of the United Provinces, to the Grand Tartar Cham Emperour of China (London: John Macock, 1669), with a 'second part' published in 1671 (London) as the Atlas Chinensis (not to be confused with the second edition published in 1673).

15 J.-B. Du Halde, Description geographique, historique, chronologique, politique, et physique de L'empire de la Chine et de la Tartarie chinoise, 4 vols. (Paris, P.G. le Mercier, 1735). 


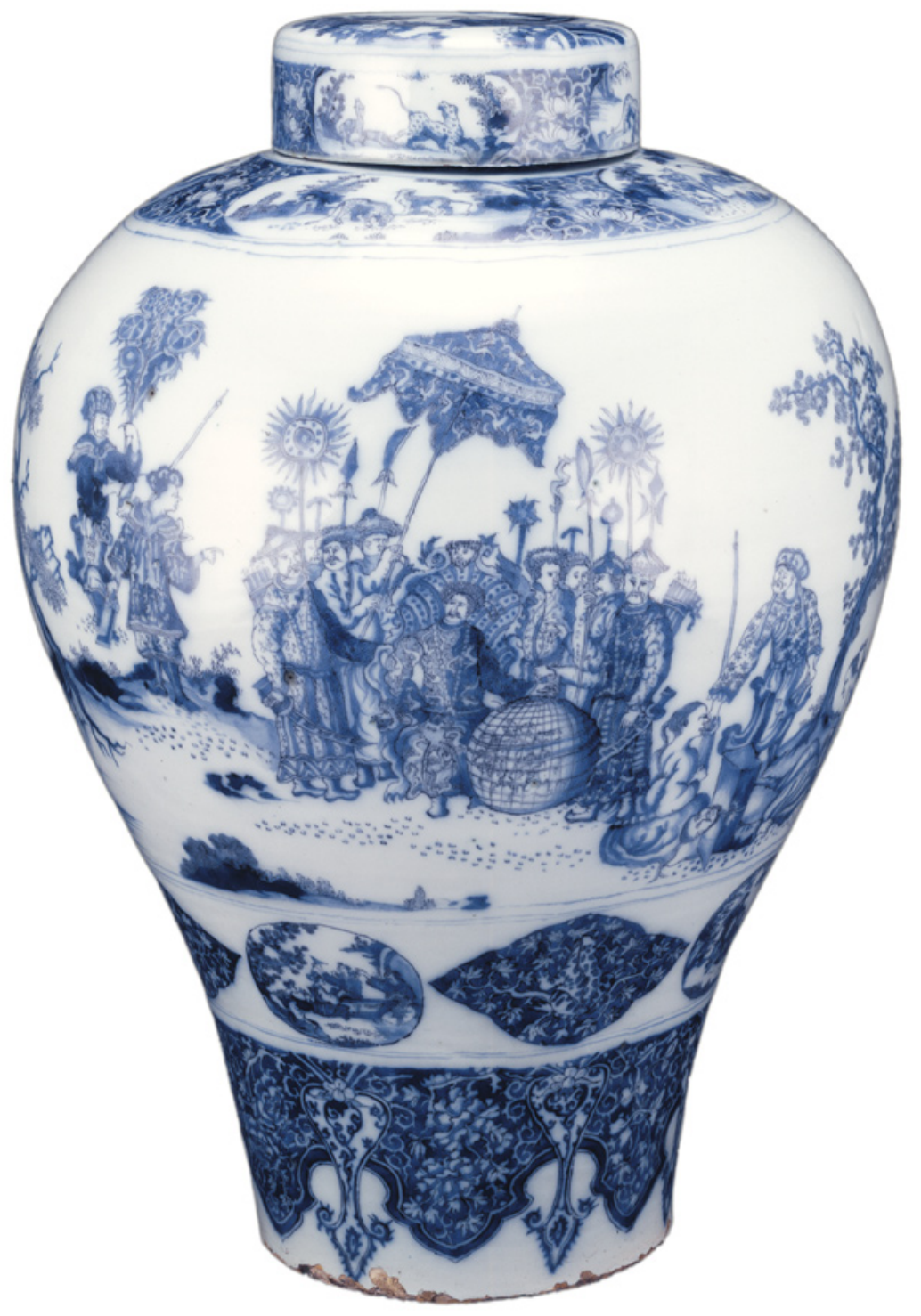

Fig. 14. Vase with Cover, ca. 1675/80, Greek A Factory (attrib.), tin-glazed earthenware, $5^{8} \mathrm{~cm}$ (height), The Art Institute Chicago, Anonymous gift in honor of Eloise W. Martin; Eloise W. Martin Fund. 
circular composition arguably enhances it: the viewer observes imperial control and its collateral damage. Still, the arabesques (top and bottom) and vignettes of exotic fauna (tigers and a rhinoceros), and the simple fact that the vase likely rested on a mantle, surely adjusts and recontextualises the meaning of Van Meurs' print. But rather than emphasise the 'decorative' aspect of the vase, we might draw the opposite conclusions: that so-called decorative arts can convey narrative; and that, in this case, the iconographic impact may not have moved so far from the frontispiece's original message of Qing imperial majesty and political might.

Emperor, entourage, and globe also appear under a tilted parasol on a large oak cabinet veneered with walnut, Brazilian rosewood, and padauk (a tropical wood), and decorated with inlaid pewter. (The cabinet was likely made circa 1700 in the workshop of Hendrik van Soest. Considerably damaged in World War II, it now resides in the Grassi Museum für Angewandte Kunst in Leipzig: see figures 15 a and b. $)^{16}$ In this instance, the original composition has changed in subtle ways - the Khan stands, the attendants recede, and the vignette now includes a richly dressed figure who offers a spread of luxury goods. Yet the side drawers of the cabinet surrounding the central imperial scene incorporate an array of exotic scenes that also derive from various, not directly related, Van Meurs' prints; and these further illustrate forms of imperial justice and control, particularly practices of Chinese legal torture (figure 15). The multiplication of somatic punishment in these images intensifies the impression of absolute imperial power, while the medium itself-exotic woods used to exhibit exotic motifs—only reinforces this message.

Another instance demonstrates even more clearly the wisdom of McLuhan's bon mot on media and messaging. A series of tapestries designed by Guy-Louis Vernansal and manufactured in the Beauvais workshops make numerous references to the Van Meurs frontispiece, along with other prints from the Nieuhof volume, in its illustration of 'The Story of Emperor of China' (as the tapestries are collectively known). In 'The Emperor on a Journey,' for example, the Great Khan sits, one arm akimbo, under an intricately designed canopy that shades a majestic throne-cum-palanquin. He is borne by attendants and accompanied by mounted escorts who bear arms and royal banners. Although the medium in this instance is neither

16 The full, undamaged cabinet is reproduced in Otto Pelka, Ostasiatische Reisebilder im Kunstgewerbe des 18. Jahrhunderts (Leipzig: Hiersemann, 1924). See also Renate Eikelmann, Die Wittelsbacher und das Reich der Mitte. 400 Jahre China und Bayern (Munich: Hirmer Verlag, 2009). 


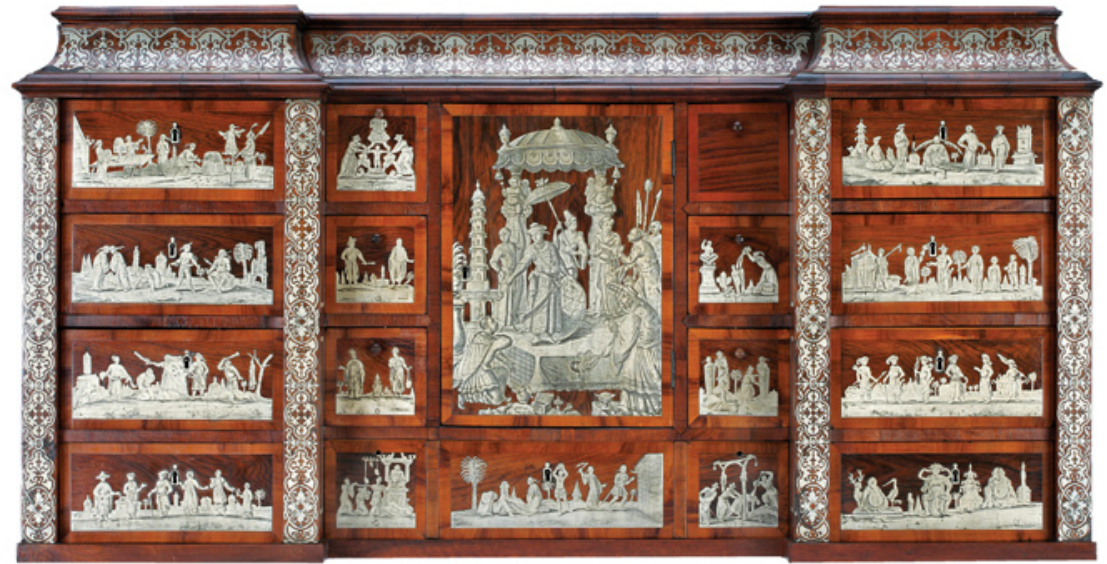

Fig. 15a. Hendrik van Soest (attrib.), Cabinet, ca. 1700, oak veneered with walnut, Brazilian rosewood, and padauk, decorated with inlaid pewter, Grassi Museum Für Angewandte Kunst, Leipzig.

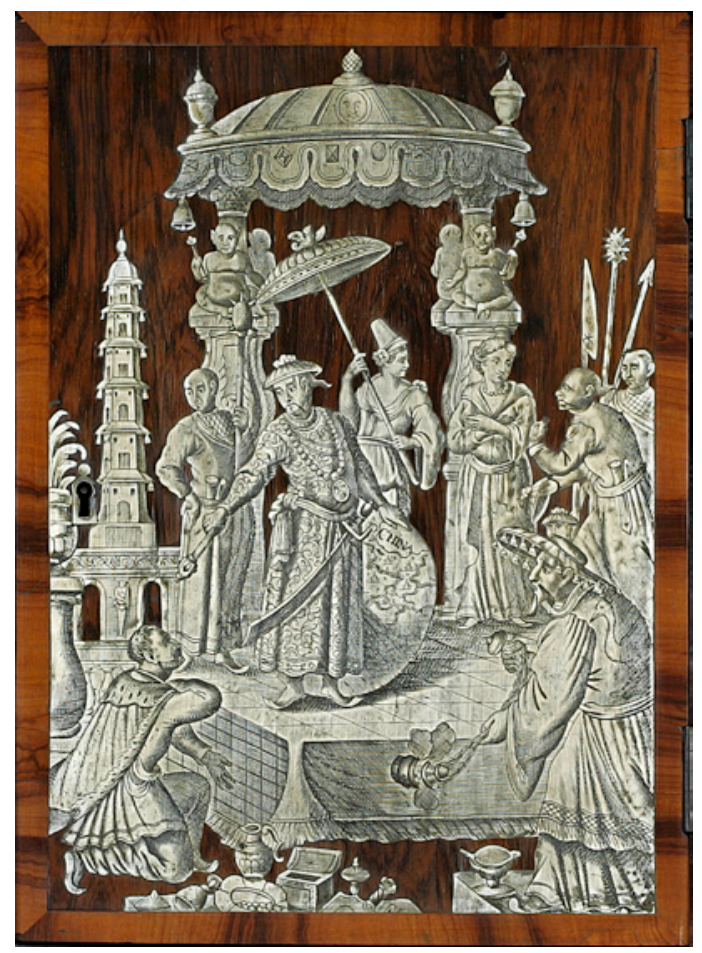

Fig. 15b. See fig. 15a. Central panel with image of the Chinese emperor. 
inherently exotic (like the tropical woods) nor formally so (like the blueand-white delftware), the message of the magnificent tapestry meshes well with the motifs of the original print: a textile fit for a prince displays the grandeur of the Chinese emperor. While it is not unusual in the European tradition to enlist large-scale tapestry for grandiose themes, the medium's deployment for 'The Story of Emperor of China' well serves this exotic, imperial narrative. More generally, while the Van Meurs frontispiece certainly travelled extensively and circuitously-from print to vase to cabinet to tapestry and so on-its mediations functioned productively, by and large, to adjust and augment the original message of what would come to be known as Oriental despotism. And while specific meanings may have shifted in individual pieces only subtly, the objects indicate collectively a more fundamental and substantive shift: In the form of a blueand-white vase, a sumptuously inlaid cabinet, and a princely designed tapestry, the original 'memory' of a putative encounter between Johan Nieuhof (and the Dutch embassy) with the newly instated Qing emperor (and his entourage) has fallen by the wayside. We have long since left the terrain of diplomatic exchange and have quietly slipped into the world of chinoiserie.

\section{Memories of Mendicants and Mandarins, or How Torture Entered the Early Modern Bedroom}

Seemingly sturdy memories can turn out to be wobbly, needless to say, and so can the texts and images that convey them. This applies especially to memories and knowledge of the exotic world - the global fare peddled in sources of early modern geography — which necessarily travelled great distances to reach consumers and left themselves open therefore to numerous imprecisions and possible interventions. Perhaps to compensate for its extensive peregrinations, geographic knowledge was typically passed off as personal account and on-site observation. Yet volumes of exotic geography were rarely the product of any singular 'author' - this applies to individual narratives such as Nieuhof's no less than to impersonal 'descriptions' (beschrijvingen) such as those of Dapper. The images that illustrate these accounts, moreover, were almost never made from bona fide witnessing (despite the persistence of this claim on the title page). When the Calvinist predikant Philip Baldaeus described for his readers the religious practices of Southern India-his self-reported 'memories' of a sojourn in Malabar, Coromandel, and Sri Lanka to observe the 
spiritual mores of the indigenes—-he borrowed said memories ('pillaged' may be too strong a word) from the manuscripts of those Jesuit missionaries who had covered this terrain a half century earlier. The images used to illustrate his account-'drawn to the life' (na 't leven), according to the title-page's breezy assertions-derived from a manuscript gifted to the Dutch governor Rijcklof van Goens by the artist Philips Angel, who had acquired and translated a journal penned by the Jesuit missionary Jacopo Fenicio. The latter had copied his images (including the volume's celebrated representation of the ten avatars of Vishnu) from a Gujarati (namely, Northern Indian) artist executed several years earlier. Baldaeus' testimony thus is not a personal memory at all—at least not in the conventional way we think of a distinctive, private memory-but rather a constructed or perhaps self-fashioned narrative, an elaborate form of cross-cultural 'telephone' wherein the starting and end points are separated by enormous gulfs of culture and context: Gujarati Hinduism, Jesuit Catholicism, Dutch Calvinism, and so on. Such forms of memories are much handled, and much gets lost (and found) in translation. ${ }^{17}$

Much gets lost and found in transmediation, as well, and this points to the material and multimedial quality of these early modern global memories. The transformation and manipulation of basic textual and graphic sources in the medium of print-words and pictures - are hardly unique. These are standard tricks of the book trade, and they cross many genres. Rather different, however, is the material transformation of imagery and motifs, or what I have been calling its transmediation: the movement of images, traces, and graphic 'memories' across media, in particular from books into material arts or what would come to be called decorative arts, and their subsequent transformations in terms of meaning. ${ }^{18}$ These transformations occurred relatively commonly to the sort of exotic motifs exemplified by the frontispiece image of emperor of China. More generally it is fair to say that exotic imagery moved easily from print

17 Philip Baldaeus, Naauwkeurige Beschryvinge van Malabar en Choromandel, der zelver aangrenzende ryken, en het machtige eyland Ceylon. Nevens een omstandige en grondigh doorzochte ontdekking en wederlegginge van de Afgoderye der Oost-Indische Heydenen (Amsterdam, 1672); Ellinoor Bergvelt and Reneè Kistemaker, De wereld binnen handbereik. Nederlandse kunst- en rariteitenverzamelingen, 1585-1735, 2 vols. (Zwolle: Waanders and Amsterdam: Amsterdams Historisch Museum, 1992), vol. 2 [catalogue], 186-187.

18 Cf. Craig Clunas, Pictures and visuality in early modern China (London: Reaktion Books and Princeton: Princeton University Press, 1997), 46, which develops a similar idea of 'iconic circuits': 'an economy of representations in which images of a certain kind circulated between [sic] different media in which pictures were involved.' 
to material arts. And this prompts the more particular question: what happens when memories of, in this case, extra-European places and things become material or 'decorative'?

An altogether different trajectory of exotic motifs can be traced back to another set of Nieuhof-derived sources, although in this case the imagery derives from a more concrete memory, a personal experience Nieuhof records in his journal on 20 May 1656, as he does other journal entries, 'for remembrance' (tot gedachtenis). On that day, while waiting on the banks of the Yangtze River not far from Nanjing, the Dutch trade delegation encountered a motley crew of local men, a scene Nieuhof worked up in a briskly executed sketch in pen and wash (figure 16). ${ }^{19}$ The figures in Nieuhof's drawing appear in an indeterminate landscape-dim allusions to mountains fill the background, yet there are no obvious signs otherwise of an exotic setting: no palms, no parasols, no pagodas-and following pre-modern conventions of composition, several distinct vignettes are combined in a single frame. The accompanying text (presumably also by Nieuhof) clarifies the subject: these are assorted beggars who perform a range of caprioles, or capers, to solicit charity from passers-by. The image offers several rich veins of inquiry - why, one wonders, is the head of the central figure so vividly aflame?-among the most curious and productive of which is the depiction of two men on the left, who hoist menacing boulders above their heads. As the narrator explains, these are blind men who, marching in order, pound stones mercilessly into their bare chests and backs 'until blood spews out'. ${ }^{20}$ And although Nieuhof seems unmoved by this garish display of masochism, a sly comment about his own belief in the Christian god suggests that he intuitively understood the sacred context of the performance: these are roadside ascetics, affiliated with the figure standing on the right, a priest, who ministers to the faithful. The sketch recollects-quite concretely and memorably-popular religious practices of early modern China.

As it turns out, this was just the beginning of the blind beggars' journey and of this particular memory's iterations. A decade or so later, the sketch was worked up in Jacob van Meurs' atelier and integrated into a print (1665), where the original meaning was partly maintained-the picture bears the title 'Mendicants,' alluding to the social context of the original drawing - yet the blind man's belly is now more comically

19 Blussé and Falkenburg, Beelden van een Chinareis, f. 101 (between pages 42 and 43).

20 Ibid., f.101 (page 44). 


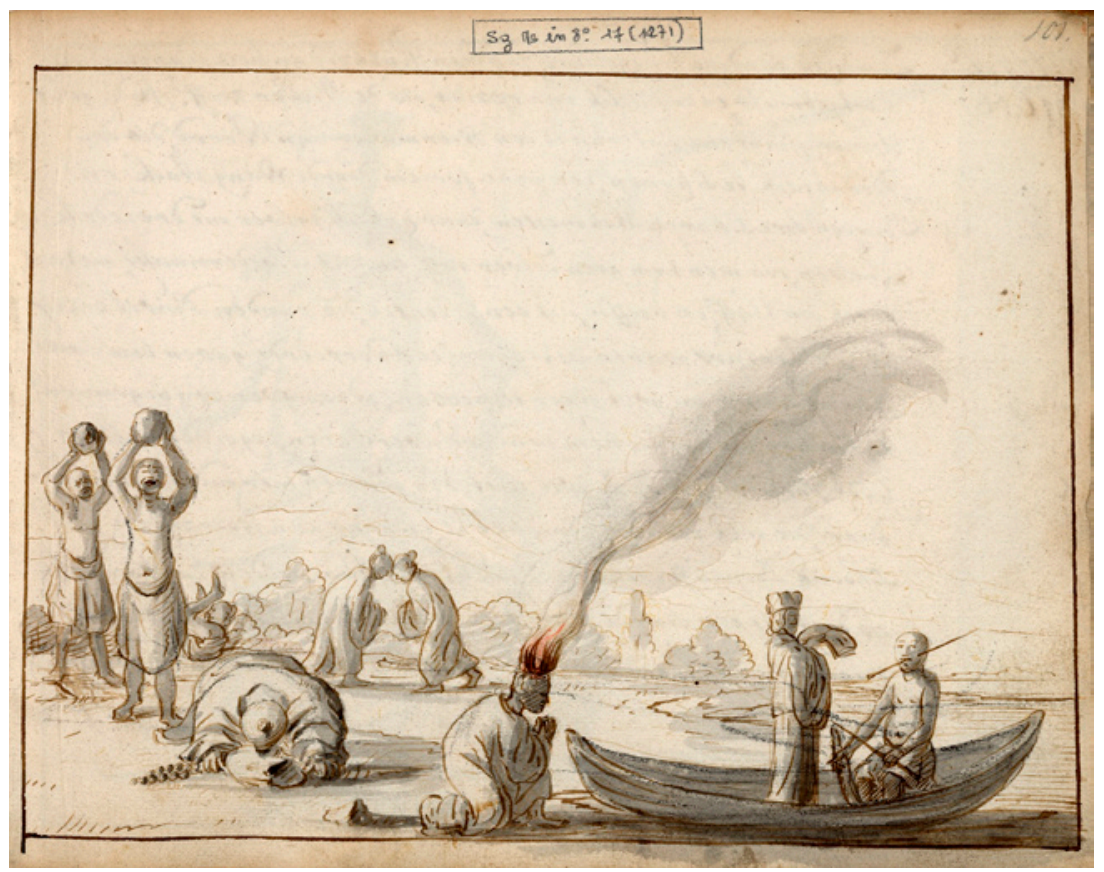

Fig. 16. Johan Nieuhof [?], drawing of ascetics in 'Journaal van zommige voorvallen, inde voyagie vande E. Heeren Pieter de Goyer en Jacob Keyser, ambassadeurs, aande grootmachtige keizer van Chyna en Tartaryen, inde jaaren 1655, 56 \& 1657' (1659), folio 101; Société de Géographie, Bibliothèque Nationale, Paris.

portly, and he joins not only the fiery figure (once again in the centre), but a wholly unrelated man in a cangue (figure 17). Very soon after that, the mendicant materialised in a painting (ca. 1666) by Jan van Kessel, where he joins a mélange of characters that includes several other members of the original cast of mendicants. Taken altogether, these figures, along with the background pagoda and several other things associated with the East, are meant to indicate all things Oriental. This is one of four Van Kessel allegories of continents, and the sum of the parts is meant to delineate the whole of 'Asia': a sweeping conflation that juxtaposes Chinese ascetics and turbaned Persians, Ottoman mosques and Buddhist statuary. ${ }^{21}$ The beggar, in all events-but one of many Asiana

21 Dante Martins Teixeira, The 'Allegory of the continents' by Jan van Kessel 'the elder' (1626-1679). A seventeenth-century view of the fauna in the four corners of the earth (Petrópolis: Index, 2002). The painting, Asie, is in the Alte Pinakothek, Munich. 


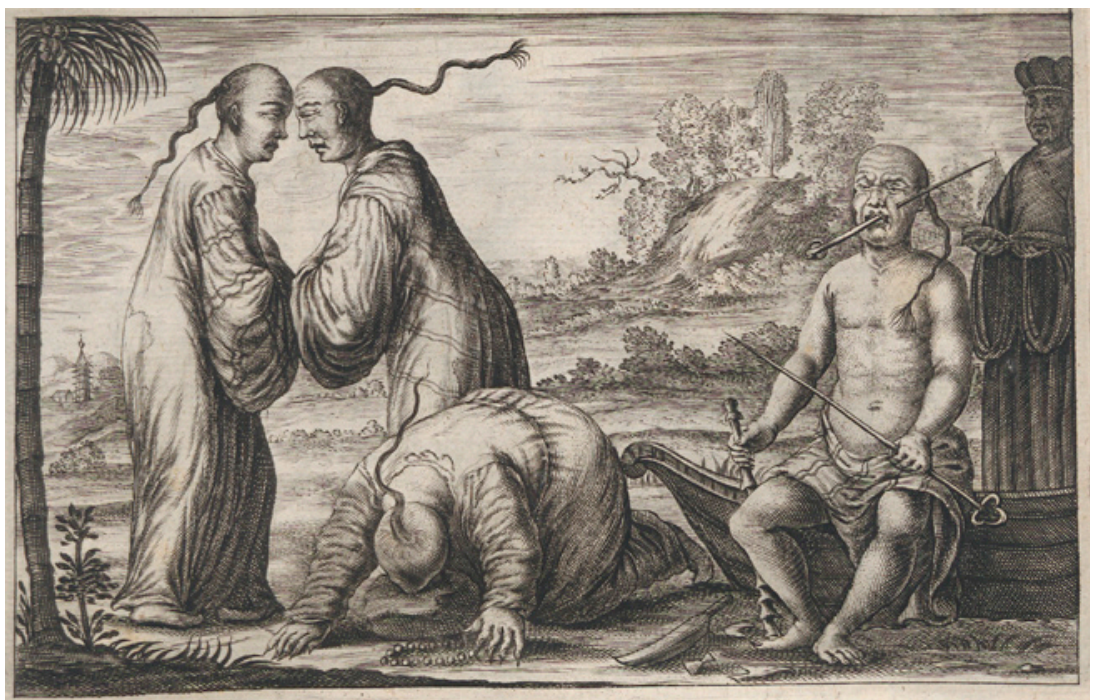

Fig. 17. Jacob van Meurs (workshop), "Mendians," engraved illustration in Johan Nieuhof, Het gezantschap der Neerlandtsche Ost-Indische Compagnie, aan den grooten Tartarischen Cham, den tegenwoordigen keizer van China (Amsterdam: Jacob van Meurs, 1665), vol. 2, p. 35, Universiteitsbibliotheek Leiden.

in Van Kessel's panel-marched on. He appeared also on a ceramic tableau made in Delft (ca. 1680-1700), where he plays the part of a strongman in a band of circus performers (mice dance beside him to the beat of a tambourine). And, after that gig, he turns up on the Grassi veneered cabinet, reunited with the not-quite flaming head (which he now readies to smash) and the stocked prisoner, who collectively make up a scene of sundry corporal punishment-Asian, one presumes, from the iconic palm trees (See figure 15a, bottom-center drawer).

It is worth noting that that these mendicants come and go with nonchalance, their place and meaning scarcely fixed. Van Meurs actually engraved several mendicants in a pair of prints (figures 17 and 18), and the lot of them undergo similar transmediations, both in clusters and on their own. Heads beat and burn on another sample of delftware: a large punch bowl, signed by Samuel van Eenhoorn (ca. 1680), which would have been used for hearty drinks after the hunt or in other carousing contexts (figure 19). And banging reverts to restrained prostration in a Rouleau vase, decorated by Ignaz Preissler around 1720. If this last rendition seems more decorous than its predecessors-it reproduces the middle mendicant of the first print (figure 17) who appears to be praying or kowtowing-, 


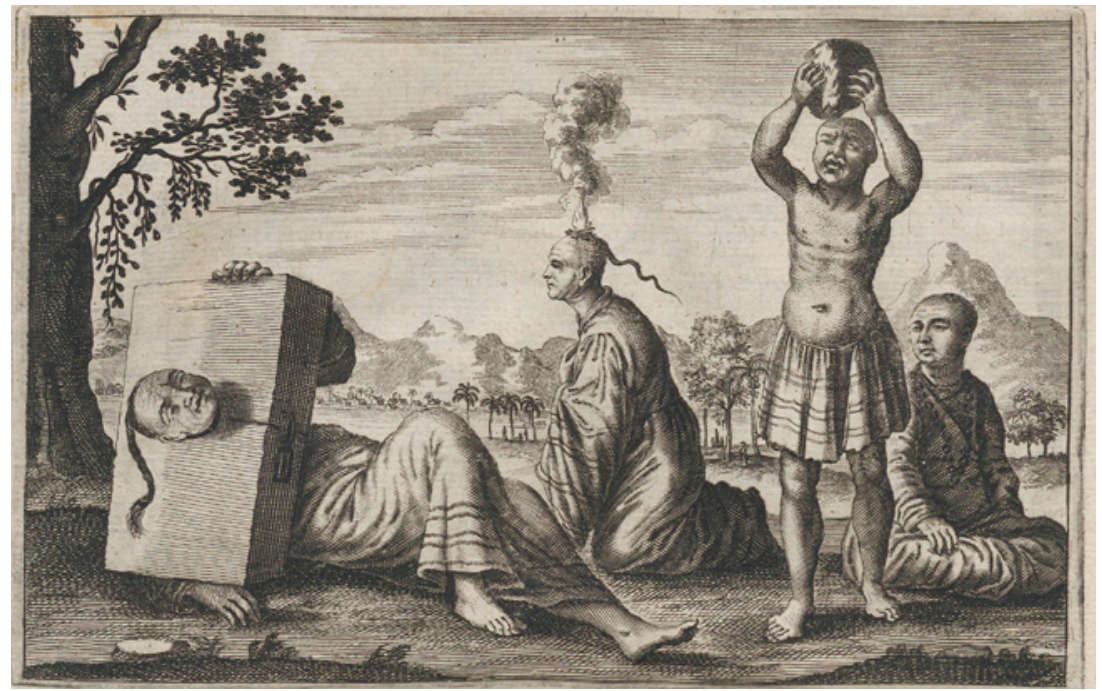

Fig. 18. Jacob van Meurs (workshop), "Mendians," engraved illustration in Johan Nieuhof, Het gezantschap der Neerlandtsche Ost-Indische Compagnie, aan den grooten Tartarischen Cham, den tegenwoordigen keizer van China (Amsterdam: Jacob van Meurs, 1665), vol. 2, p. 36, Universiteitsbibliotheek Leiden.

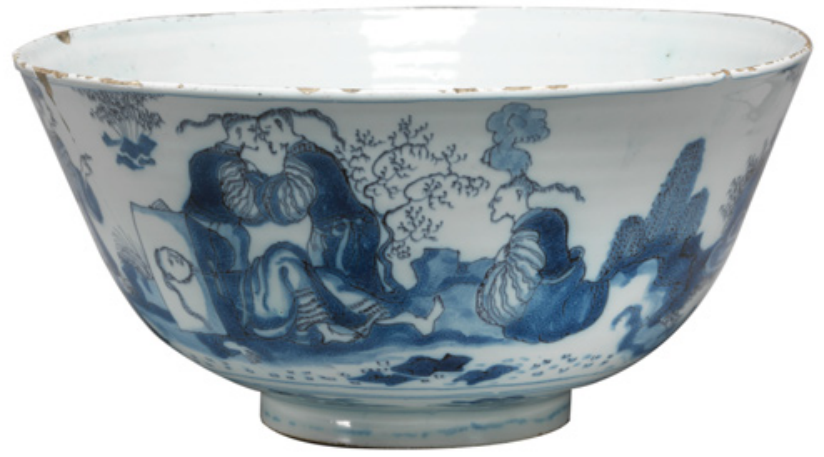

Fig. 19. Samuel van Eenhoorn, Greek A Factory, Punch bowl, tin-glazed earthenware, (ca. 1680), The Fitzwilliam Museum, Cambridge. 
that may owe to its extraction from a pattern book by Johann Christoph Weigel, which codified the image of this particular mendicant, albeit in an altered setting and with a revised meaning. Rather than the original emphasis on bodily harm and endured pain - the original image makes a point about religious practices in rural China-the message is now predicated on fantasy and pleasure. This is most certainly the sense suggested by the long-wandering exotic mendicant who appeared in the Bavarian pleasure palace Amalienburg on the grounds of Nymphenburg, by now a kowtowing prop for a prancing squirrel. ${ }^{22}$

Yet another mendicant leads us down yet another trail, prompted, yet again, by distant memories of the exotic world. The cangued figure in one of the two Van Meurs prints relates to no original drawing we know of-and presumably to no documented memory-yet it does resemble an image implicitly ascribed to Nieuhof: the frontispiece depiction of the dreadfully suffering subjects (including one in a cangue) who beseech the Great Khan for mercy (see figure 18 and compare figure 12). This image certainly implies memory: it opens and gives visual form to a volume of self-declared 'memorable occurrences' in the East. Yet the image also serves, more subtly, to arrest the reader-viewer's attention in a strikingly memorable way. A form of portable pillory used for corporal punishment in pre-modern China and an object of great fascination to early modern Europeans, the Oriental cangue - the object occurred, of course, also in the Occident, for example in New England-appeared in several Dutch-made prints spanning several publications. It came to stand for the power of the Great Khan over his subjects' bodies (as in the Nieuhof frontispiece) and for habits of 'popular' asceticism among exotic 'mendicants.' This popularity soon ushered the image from prints to material arts. Among the chief sources mediating this transition was John Stalker and George Parker's Treatise of Japaning and varnishing, a how-to book for the art of lacquer. ${ }^{23}$ The Nieuhof-inspired cangued figure, as rendered in the lacquer manual, is slyly extracted from its original imperial setting: gone is the central figure of the Khan. This revised version, rather, serves Stalker and Parker as décor for an inkstand or comb box (as they advise the practitioner): a slick pastiche of corporal punishment for the well-provisioned gentleman. Another pattern offered in the Treatise of Japaning, likewise derived from

22 See Ulrike Kiby, Die Exotismen des Kurfürsten Max Emanuel in Nymphenburg (Hildesheim: Georg Olms, 1990) 79-80 and 274-75.

23 John Stalker [and George Parker], A treatise of Japaning and varnishing, being a complete discovery of those arts (Oxford: John Stalker, 1688). 


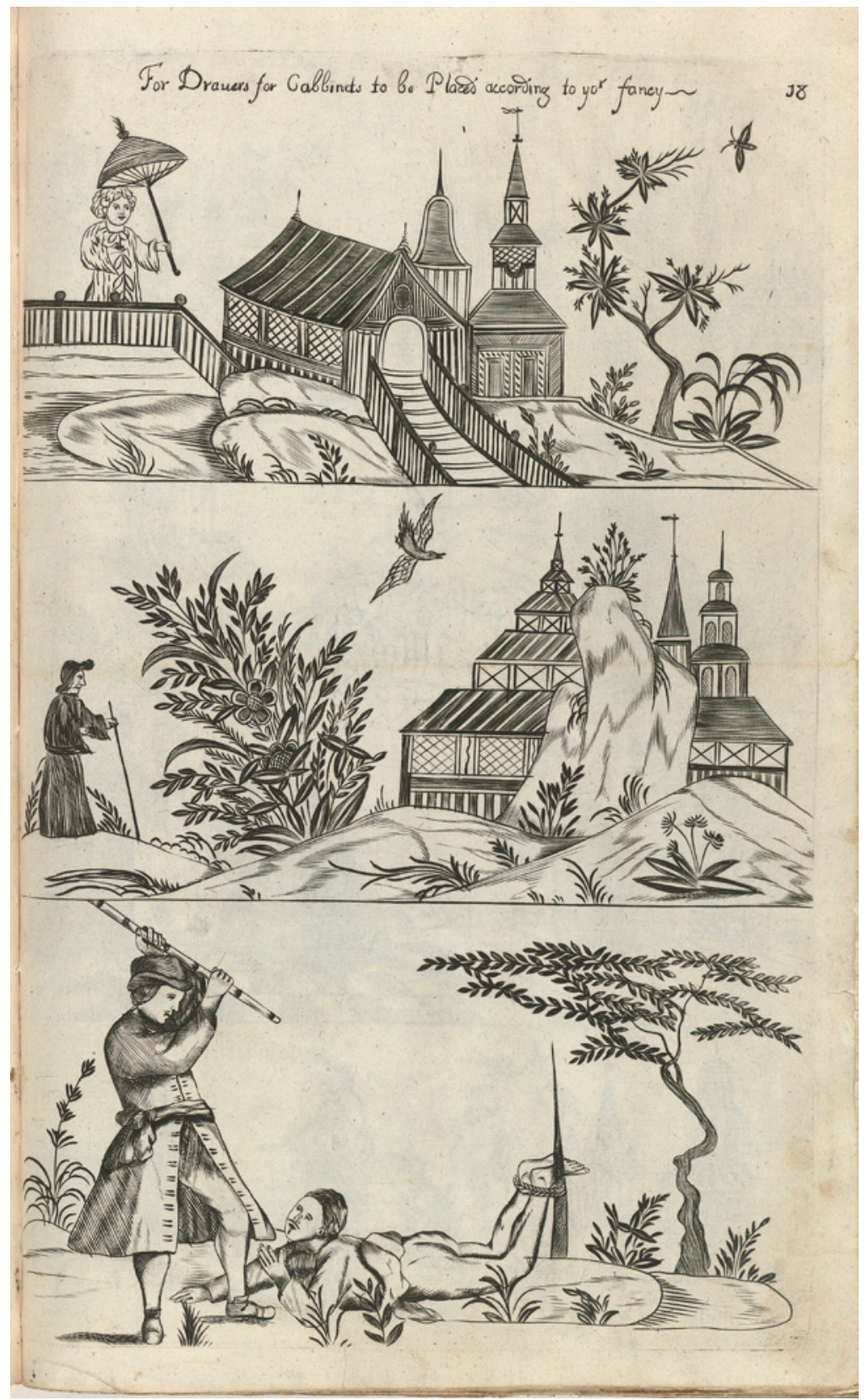

Fig. 20. John Stalker and George Parker, "For Drawers for Cabbinets to be Placed according to your fancy" (plate 18), engraving in Stalker and Parker, A treatise of Japaning and varnishing (Oxford: John Stalker, 1688), Rijksmuseum Amsterdam. 
a printed geography book and lately redesigned by Stalker and Parker 'for [the] cabinets' of a gentleman, shows an even more disturbing image: the methodical thrashing of a bare-buttocked prisoner with a bamboo cudgel, a technique of torture traditionally referenced in modern sources by its Spanish name, the bastinado (figure 20).

In this case, we can trace the image backward as well as forward, and thereby follow its transmediations from personal, site-specific memoryan image in a discreet time and space - to provocative, readily adaptable décor. Looking backward, then forward: Stalker and Parker borrowed the caning pastiche from another Van Meurs publication, in this case Olfert Dapper's account of the 'memorable affairs' of the Dutch East India Company in China. ${ }^{24}$ Textual references to caning merited two engravings from Van Meurs' atelier. In one the victim is a mandarin, identified by the garments strewn about in the foreground; the victim faces a bland landscape on the wall, while a casual witness peers in from an open window (figure 21). In the second print the subject lies grimacing, face in dirt, while a handful of other prisoners cower in the background, naked in the cold air as they await their turn (figure 22). Both images pertain to descriptions of the Chinese legal system: they depict the public spectacle of imperial justice - wrongly, scholars have pointed out ${ }^{25}$ — and the awesome power it had over the body public. Stalker and Parker's rendition, taken directly from the open-air scene, streamlines and repurposes the Van Meurs engraving and subtly changes its meaning. Absent are the background edifices and throng of victims; meanwhile, the efficient executioner is replaced by a well-dressed figure whom the victim implores for mercy (compare figures 20 and 22). While the Van Meurs image underscores the power of the judicial system and the emperor by extension-present metonymically in the grand architecture placed in the rear-Stalker and Parker personalise the exchange, granting discretion to the caner. Indeed, they may undermine the original message of the emperor's sole legal authority. More to the point, Stalker and Parker bring the image into a domestic setting. And this is even more the case for two 'scenes of caning' done on embroidered silk wall-panels, created for a South German

24 Olfert Dapper, Gedenckwaerdig bedryf also known by its English title, the Atlas Chinensis.

25 Timothy Brook, Jérôme Bourgon and Gregory Blue, Death by a thousand cuts (Cambridge, Mass.: Harvard University Press, 2008). See also Jérome Bourgon, 'Chinese executions. Visualising their differences with European supplices', European Journal of East Asian Studies 2, no. 1 (2003), 153-184. 


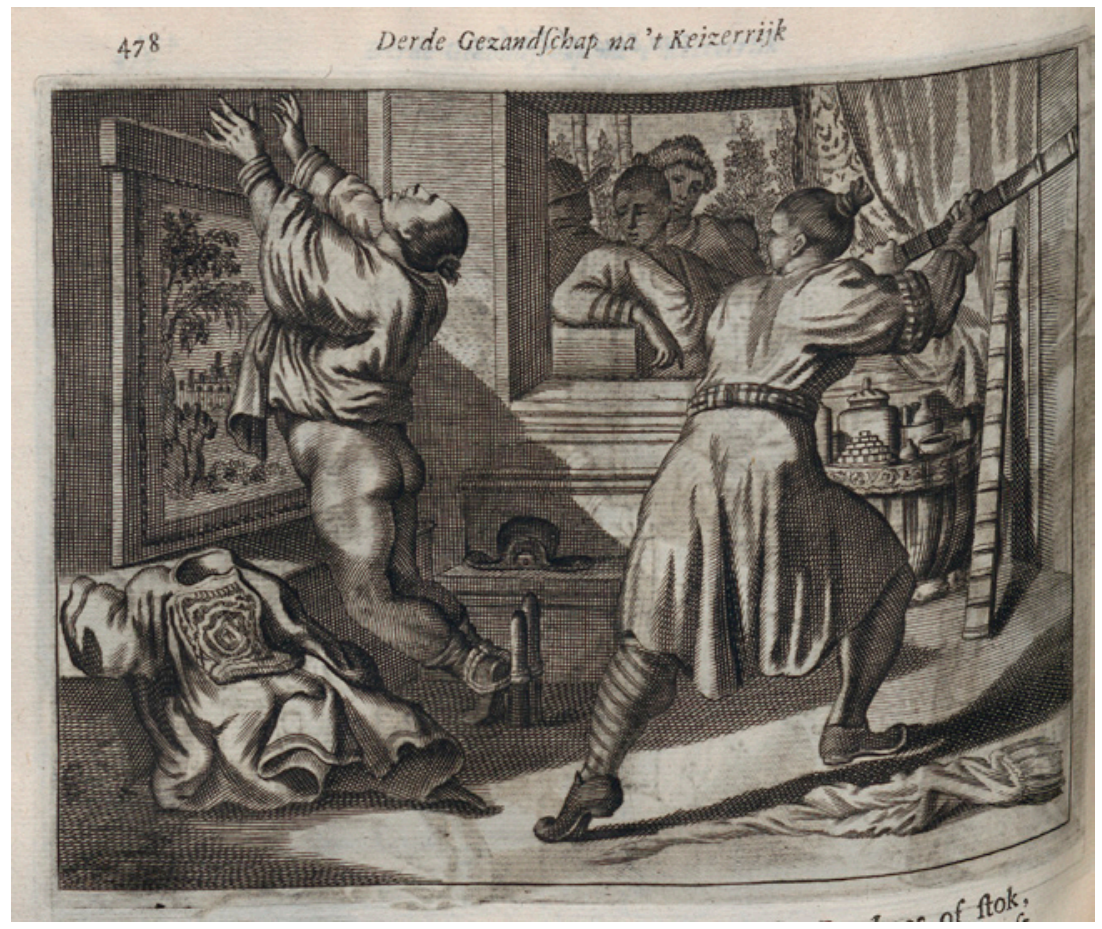

Fig. 21. Jacob van Meurs (workshop), "Caning", engraved illustration in Olfert Dapper, Gedenckwaerdig bedryf der Nederlansche Oost-Indische Maetschappye, op de kuste en in het keizerrijk van Taising of Sina (Amsterdam: Jacob van Meurs, 1670) p. 478, Universiteitsbibliotheek Leiden.

drawing room and later deployed for a Bavarian bedroom (figure 23). ${ }^{26}$ This vignette combines Dapper-Van Meurs' two images, includes the background architecture, and inserts two conspicuous palms, which serve to enhance the exotic flavour of the scene. Yet the care of the scene-setting notwithstanding, the purposeful depiction of a caning pastiche prompts an obvious question: Why would early modern Europeans put scenes of torture in their bedroom? This, in turn, recalibrates our broader inquiry into form and meaning: How are memories transformed when they move from text to artefact, print to design, and book to bedroom?

Looking further backward is further helpful. Original sketches do exist for the caning images, and while these are altogether detached from the text compiled by Dapper, a hack writer at best, they are intimately con-

26 Eikelmann, Die Wittelsbacher und das Reich der Mitte, 264-269. 


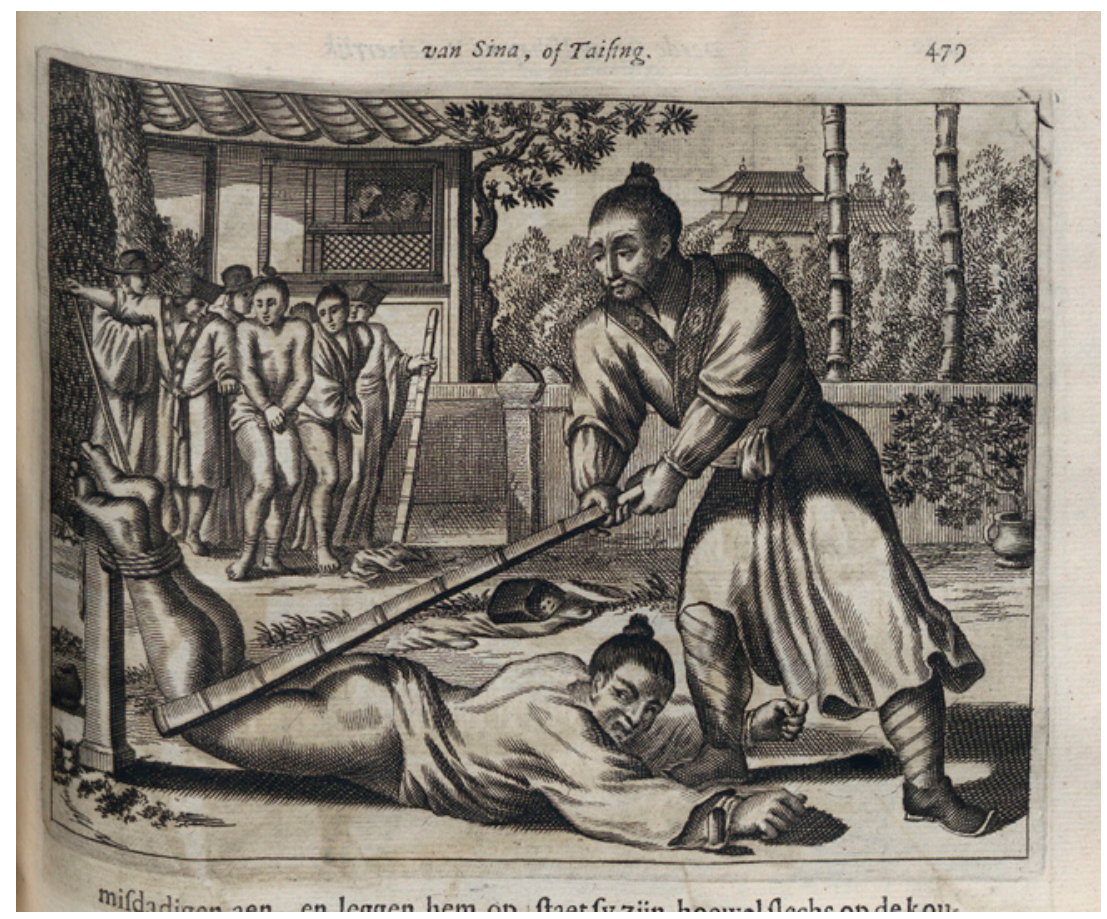

Fig. 22. Jacob van Meurs (workshop), "Caning”, engraved illustration in Olfert Dapper, Gedenckwaerdig bedryf p. 479, Universiteitsbibliotheek Leiden.

nected to a particular memory. Dapper worked for his publisher, Jacob van Meurs, in the business of geography. ${ }^{27}$ The source for caning, by contrast, came from the Jesuit scholar and intrepid traveller, Adriano de las Cortes, who spent time in China and composed a genuine and 'memorable' description of the regime in 1625 - a full century before caning enters the European bedroom. ${ }^{28}$ De las Cortes offers an entirely stripped-down depiction of caning (figure 24). He emphasises, if anything, the rank of the guilty party - no one is above imperial rule - a point alluded to by the victims' hats and tunics. Text and image underscore the disciplined, workmanlike labours of the executioner, a mere servant of the Ming emperor-Ming, since the sketches date from the moment the Ming were just fending off Manchu invaders. Relations with the elite classes of the

27 John E. Wills, Jr., 'Author, publisher, patron, world. A case study of old books and global consciousness', Journal of Early Modern History 13 (2009), 375-433.

28 Adriano de las Cortes, Le voyage en Chine d'Adriano de las Cortes, s j, 1625, ed. Pascale Girard, trans. Pascale Girard and Juliette Monbeig (Paris: Chandeigne, 2001). 


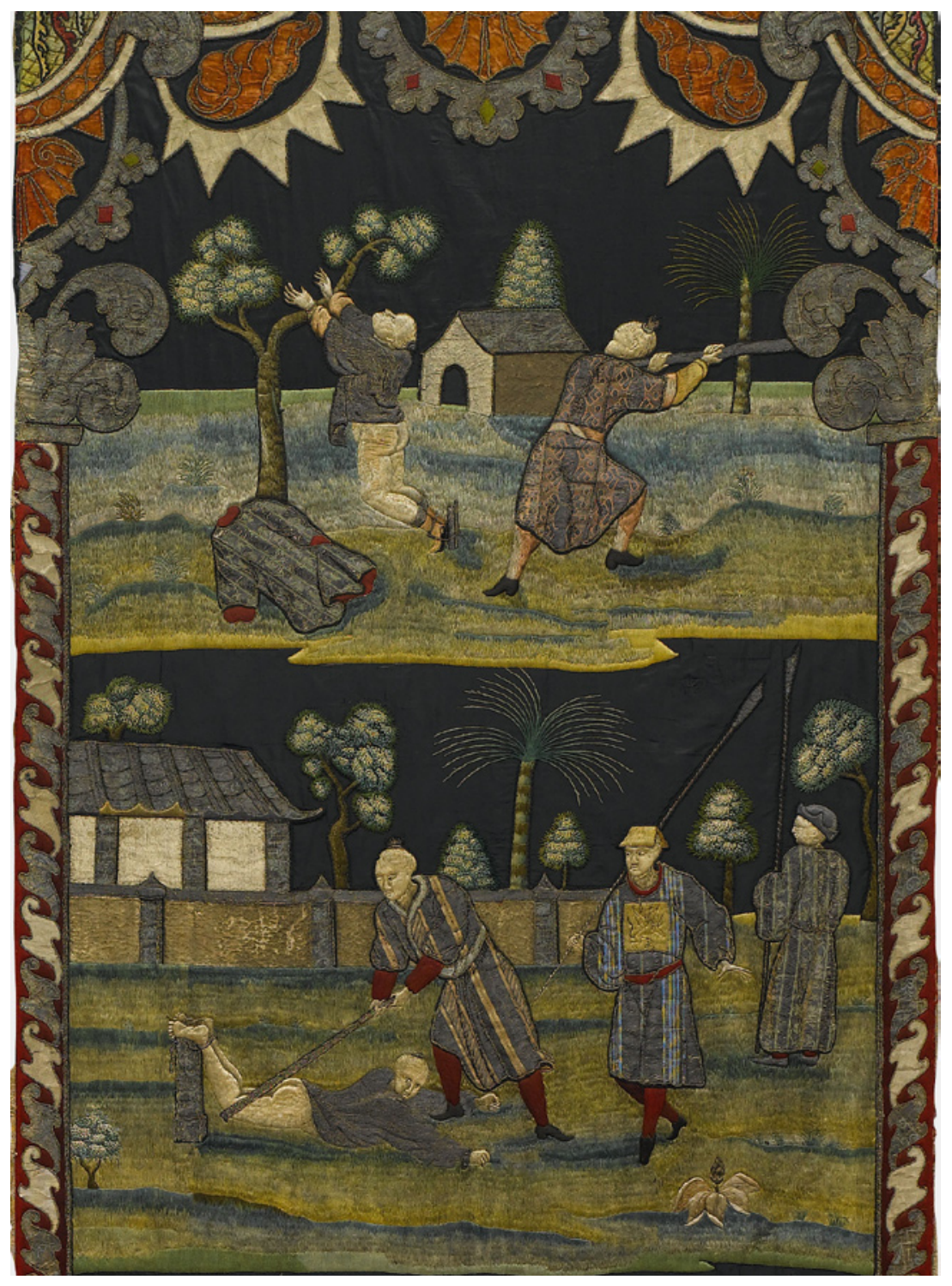

Fig. 23. Wall panel, silk with linen, ca. $1700,328 \mathrm{~cm}$ (height) $\times 96$ (width per panel) Bayerische Verwaltung der staatlichen Schlösser, Gärten und Seen, Residenz München. 


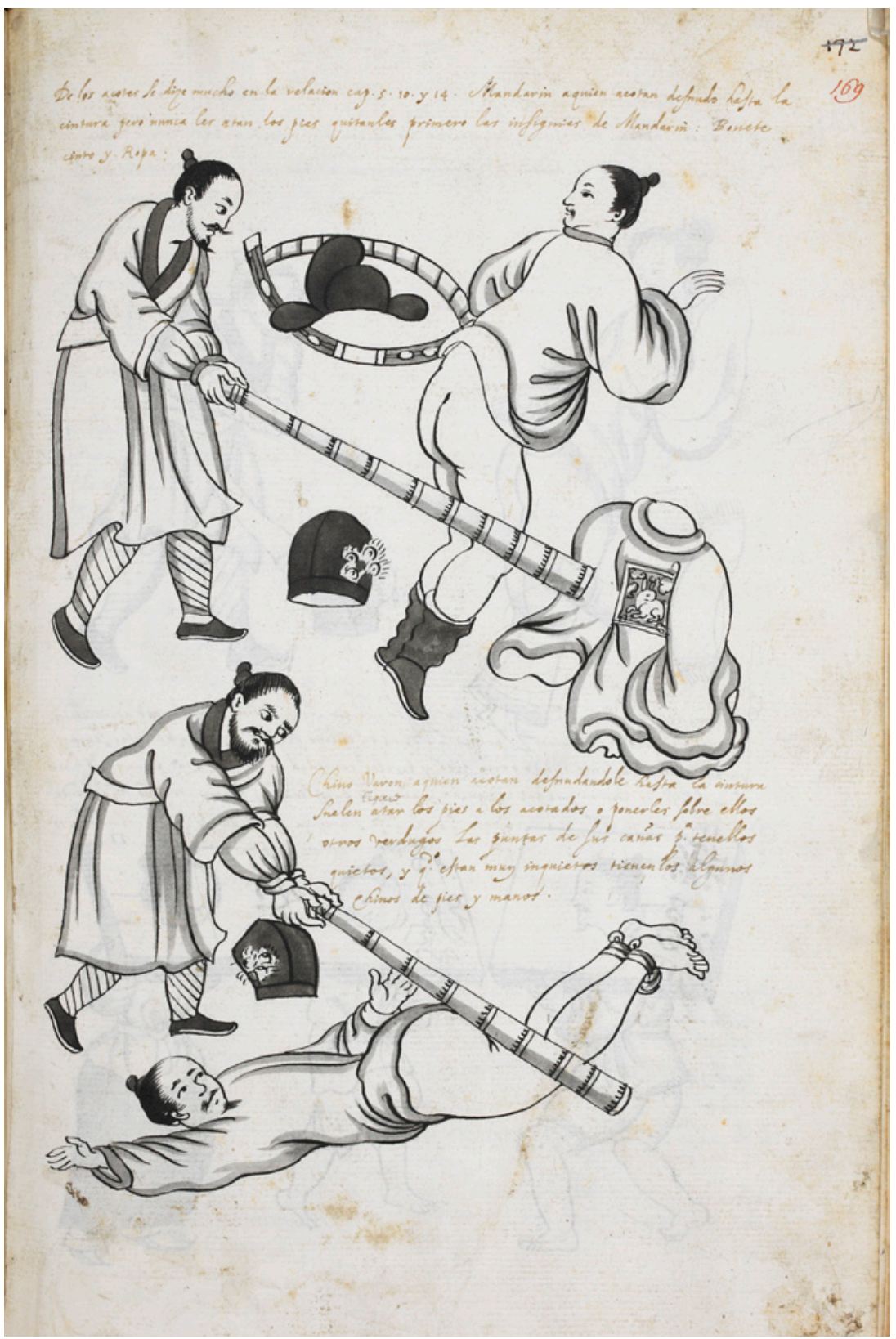

Fig. 24. Adriano de las Cortes, 'Relation, with drawings, of his voyage, shipwreck, and captivity at Chanceo in China: 1621-1626', fol. 169 recto, British Library, mss. Sloane. 
regime were vital to de las Cortes and his Jesuit patrons, whose project of evangelisation entailed forming alliances with high-ranking officials. In the context of de las Cortes' manuscript, this bona fide, reportedly eyewitness, assuredly memorable experience and the knowledge it conveyedpolitical and judicial insights into how the imperial Ming government operated, with tactical religious implications-had a practical, precise, and pressing purpose. Yet this manuscript lay unpublished for nearly four centuries. In the hands of Van Meurs, by contrast, and in the medium of print - print that successfully and profitably crossed confessional and linguistic lines — de las Cortes' memories and images are transformed to make a hazier point about Oriental power and imperial 'tyranny.' And in the hands of Stalker and Parker and the maker of the silk wall-panels, medium and message have changed - have transmediated-once again: Chinese torture is now allied with the delights of the bedroom. Narratives of Asian politics, reports of imperial governance, and observations of Ming judicial regimes have been reassigned, as canny producers convert Jesuit memories of corporal punishment into provocative pastiches of 'decorative' torture. Memories of pain have transmogrified into pastiches of pleasure.

\section{Producing and Consuming Early Modern Memories (Memory Sells)}

In a certain sense, images of the exotic world, which have provided the material for this cursory foray into memory and its mediations, may have lent themselves to this sort of transformation. Producers in the business of exotic geography manipulated texts and illustrations of far-away places to their advantage; while consumers, who obviously had an great appetite for this fare, had meagre means to verify these workshop interventions. Yet this may be too easy an explanation. Sources of geography (and this goes for texts as well as images) were keen to emphasise their veracity, their authors' high credentials, the eye-witness validity of their reporting, and their expressly 'memorable'-and thus implicitly reliable-portraits of the world. Geography was (and is) a science. Yet geography is also something more: it was (and is) a genre of consumable products of immense attraction. It might be understood, further, as a process of representation whereby particular memories of specific places are translated into varying and generic material forms-books, to be sure, yet also a vast array of images and objects. And these various forms indubitably shape various meanings - which brings us back to Marshall McLuhan and his prescient observation about the medium and the message. 
McLuhan, a celebrated philosopher and literary critic, is typically cited as one of the founding fathers of media studies. ${ }^{29}$ Yet it is worth recalling the influence that McLuhan also had on Madison Avenue in its 196os heyday and on the world of advertising, and it is worth noting the commercial implications of his theories of mediation. Memories surely follow many iterations - they are much handled commodities - and in their many forms, they not only take on new meanings but also obtain new values. Early modern Europe's understanding of the non-European world derived increasingly from texts and pictures built upon the actual memories of travellers and merchants who ventured abroad, expanding Europe's world of commerce and empire - this marks the great shift in the genre away from its medieval antecedents and toward a more modern geographic science. ${ }^{30}$ Yet this brief overview of early modern sources of geography-sources extracted from a traveller's direct engagements, a merchant's personal experiences, or a missionary's concrete memories-demonstrates how these reports and representations could produce something quite different. And this suggests, in turn, a broader understanding of how geography works and how memory works: how an encounter with a roadside ascetic in rural China could shape the exotic design of a ceramic punch bowl; or how an audience with a provincial viceroy could transform into a cabinet commemorating Oriental despotism; or how an eyewitness report of Ming judicial policy could produce quasi-decorative violence in a Bavarian bedroom. In all these cases, personal memories and parochial reportsaccounts that derive from the particular perspectives of an evangelizing Spanish Jesuit or an entrepreneurial Dutch merchant-could ultimately translate into generically European images of the exotic world: of Oriental despotism, heathen religion, Chinese torture, and so on. To understand these processes of transformation, one might also invoke, along with McLuhan, the sociologist of science Bruno Latour, who has studied the transition of what Latour calls local knowledge-a personal encounter or site-specific memory, for example, set in a specific context-into what Latour terms universal knowledge: a broadly understood conception of

29 Philip Marchand, Marshall McLuhan. The medium and the messenger, (rev. ed., Cambridge: The MIT Press, 1998).

30 On this moment of transition, see Joan-Pau Rubiés, Travel and ethnology in the renaissance. South India through European eyes, 1250-1625 (Cambridge: Cambridge University Press, 2000); Joan-Pau Rubiés, 'Travel writing as a genre. Facts, fictions and the invention of a scientific discourse in early modern Europe', International Journal of Travel and Travel Writing 5 (2000), 5-33; Palmira Brummett (ed.), The 'book' of travels: genre, ethnology and pilgrimage, 1250-1700 (Brill: Leiden, 2009). 
(in this case) the exotic world, as circulated in the Europe-wide sources this essay has referenced. ${ }^{31}$ In the transmediations of a Jesuit memory or a VOC embassy we can discern 'European' (rather than Spanish or Dutch) conceptions of the world. These transmediations demonstrate, in other words, how so-called counter memories are subtly and cannily produced, not uncommonly through the efforts of enterprising ateliers.

And this brings up a final point, which relates precisely to the production as well as consumption of memory. It is always more challenging for scholars of the past to analyse the consumption, rather than production, of culture: in this case, how (or even if) various material vestiges of memory-printed descriptions, engraved illustrations, painted objects, and so on -were ultimately consumed, utilised, and assimilated by early modern Europeans. They would have been consumed ('read') differently, we might assume, according to their different material forms. Yet we might be on safer ground if we consider, rather than consumption, matters of production and indeed one of the central questions posed by this volume pertaining to the authority over memory: who ultimately made and managed early modern memories? In the case of early modern sources of geography, in the moment of their enormous expansion and terrific popularity in the late-seventeenth and early-eighteenth centuries, our answer should take into account the role played by canny producers and inventive ateliers - the commercial angle and the profit motive of producers, in other words. Memory is an indubitably valuable commodity, and the profit to be extracted by rendering a 'memorable' sketch of Chinese justice into a no less memorable pastiche of titillating violence-for printed books, for household ceramics, for bedroom wall-panels-must have been considerable. As our modern mavens of memory have amply demonstrated, whether from the perspective of Madison Avenue or Hollywood or Fleet Street, memory sells. Its sales, moreover can take many, also material, forms. Whether we wish to call the redeployment of early modern memories, such as those of Johan Nieuhof and Adriano de las Cortes, a modern phenomenon or not seems moot. In all cases, the processes of these memorable transmediations and the images they produced have bequeathed to us rich and evocative forms of the early modern world, with which we still grapple to this day.

31 Bruno Latour, Science in action. How to follow scientists and engineers through society (Cambridge, Mass.: Harvard University Press, 1987), esp. 215-257. 